\title{
Ovid and Titian 2012
}

\section{Fiona Macintosh ${ }^{1}$}

Published online: 8 May 2019

(c) The Author(s) 2019, corrected publication July 2019

Titian 2012 was a highly ambitious project, involving the worlds of dance and the visual arts, and formed part of Britain's Cultural Olympiad for the London Olympic Games in the summer of 2012. Titian 2012 also marked two other cultural landmarks that year: first, the retirement of Monica Mason after fifty-four years with the Royal Ballet and ten years as its Artistic Director; and second, the purchase in March of Titian's Diana and Callisto (1556-9) from the Duke of Sutherland by the National Galleries of Scotland and England. This purchase meant that the painting was reunited, for the first time since the late eighteenth century, with Titian's two related, Ovid-inspired artworks, Diana and Actaeon (1556-9) and The Death of Actaeon (1556-75), both already in the galleries' collections. ${ }^{1}$

Instigated and inspired by Minna Moore Ede, then Assistant Curator of Renaissance paintings at the National Gallery, and supported by the energy and commitment of Monica Mason, the collaboration between the National Gallery and the Royal Ballet included commissioning fourteen poets to respond to the paintings (among them, Seamus Heaney, Carol Ann Duffy, Tony Harrison and Simon Armitage, for whom Greco-Roman antiquity is a regular source of inspiration). ${ }^{2}$ Three visual artists - the sculptor, Conrad Shawcross; the conceptual artist, Mark Wallinger; and the painter, Chris Ofili - were invited to produce work for exhibition alongside the Titians in the National Gallery and to design the sets and costumes for the ballets that were to be performed at Covent Garden.

Shawcross's Trophy consisted of a carved wooden antler and a sinewy and seductive robot, which was scaled up for the Covent Garden stage to become the vast mechanical Diana in the ballet entitled Machina, which will provide the focus of this discussion. Wallinger's Diana was an installation featuring real-life Dianas inside a fully plumbed bathroom, into which the viewer was invited to peep voyeuristically

\footnotetext{
1 See http://www.nationalgallery.org.uk/whats-on/exhibitions/metamorphosis-titian-2012 [accessed 16 May 2018]. See further M. Moore Ede, Metamorphosis: Art, Music, Dance, London, 2013; and BBC One's Imagine programme, 'Dancing with Titian', 24 July 2012.

2 The poems by the sixteen poets are printed in N. Penny, Metamorphosis: Poems Inspired by Titian, London, 2012.
}

Fiona Macintosh

fiona.macintosh@classics.ox.ac.uk

1 St Hilda's College, Cowley Place, Oxford OX4 1DY, UK 
through tiny portholes and catch a glimpse of the bathing woman/goddess; and Wallinger's concave-mirrored set for the ballet Trespass continued the theme of transgressive spectating. The third exhibit at the National Gallery alongside the Titians was Ofili's seven lush and sensuous paintings, recalling Klimt and Rousseau and Gaugin by turns in their fusion of the natural and human worlds; and these canvases were replicated in the vast backdrops on stage at the Royal Opera House for Diana and Actaeon. There were seven choreographers for the three ballets (Wayne McGregor and Kim Brandstrup for Machina; Alistair Marriot and Chris Wheeldon for Trespass; and Liam Scarlett, Will Tuckett and Jonathan Watkins for Diana and Actaeon). Finally, three composers joined (and often led) the teams: Nico Muhly for Machina; Mark Anthony Turnage for Trespass; Jonathan Dove for Diana and Actaeon.

In some ways it was hardly surprising that dance was included in a project stemming from Ovid's Metamorphoses: epic, in general, and the Metamorphoses, in particular, have proved invaluable sources of inspiration for choreographers since the birth of modern ballet at the start of the eighteenth century, when the institutional divisions in the arts were formally established. Indeed, the first and second ballets d'action, the forerunners of modern ballet, by the dance master/choreographer, John Weaver, The Loves of Venus and Mars (1717) and Orpheus and Eurydice (1718) may well have looked back to Greco-Roman antiquity's most popular performance art form, the ancient pantomime, for their model; but the content of Weaver's ballets came directly from the Metamorphoses (and in the case of The Loves of Venus and Mars, indirectly at least from Odyssey Book VIII). ${ }^{3}$

The Russian ballet impresario and founder of the Ballets Russes in 1909, Sergei Diaghilev was routinely invoked as a guiding spirit for the ballets in Titian 2012. And since Diaghilev proclaimed that the Ballets Russes had achieved the genuine Gesamtkunstwerke, to which Wagner had aspired but had himself never produced, ${ }^{5}$ there is a sense in which Monica Mason was cast in the role of a bold, if far less imperious, Diaghilev in her position as impresario over the synthesis of the arts at Covent Garden. It was a rare privilege for any Artistic Director of any ballet company since Diaghilev to be given the opportunity to place leading composers and visual artists together with the world's most-sort-after choreographers and dancers. Moreover, Monica Mason's inspired but also surprising pairings of personnel recalled aspects of the Ballets Russes's tradition as well. But it may also have been Nijinsky's indirectly Ovidian L'Après-midi d'un faune (1912) that called the Ballets Russes to mind whilst watching Titian 2012. The action of Nijinsky's ballet, against Léon Bakst's stunning designs and to Debussy's haunting score, proved highly controversial because the faun (danced by Nijinksy himself) concluded the

\footnotetext{
${ }^{3}$ On the ancient sources of ballet d'action, see E. Hall, 'Ancient Pantomime and the Rise of Ballet', in New Directions in Ancient Pantomime, ed. E. Hall and R. Wyles, Oxford, 2008, pp. 363-77; and I. LadaRichards, 'Dead but not Extinct: On Reinventing Pantomime Dancing in Eighteenth-Century England and France', in The Ancient Dancer in the Modern World, ed. F. Macintosh, Oxford, 2010, pp.19-38.

4 See for example R. Fairman, Financial Times, 9 June 2012; J. Mackrell, Guardian, 15 July 2012; M. Monahan, Telegraph, 16 July 2012; G. Dowler, classicalsource.com, 17 July 2012.

5 M. Eksteins, Rites of Spring: The Great War and the Birth of the Modern Age, London, 1990.
} 
twelve-and-a-half-minute dance drama with an orgasmic crescendo conducted upon the scarf of one of the nymphs.

Should we, then, see Titian 2012 as some kind of return to the high watermark of cultural modernism, and especially the work of the Ballets Russes from 1911 onwards, which stunned and shocked audiences with its visual, musical and moral dissonances? Titian 2012 also elicited excitement, dynamism and, to a lesser degree, controversy, with its own disjunctions and its unusual collocations. It was notable for its juxtaposition of markedly different choreographies - for example, the intense physicality of McGregor's choreographic style with the achingly lyrical movement vocabulary of Brandstrup. As Brandstrup himself noted of Machina:

Conrad [Shawcross]'s industrial mobiles versus Titian's sensuous flesh, Nico [Muhly]'s rhythmically propelled music versus William Byrd's hymn, and Wayne [McGregor]'s physical language alongside mine all seemed at first sight to be incompatible .... [But they] gave the piece a tension and dynamic life that none of us would have found on our own. ${ }^{6}$

But Titian 2012 was by no means an attempt to recover a past moment; it was very much of the moment, with its live screenings beyond the Royal Opera House and the National Gallery informed by the laudable widening communities agenda that sought to bring traditionally 'elitist' cultural events into public places and to provide access free of charge.

This article focuses on one of the ballets, Machina, in order to proffer another genealogy to Titian 2012 - one that relates to the broader history of epic on stage and its complex relationship to tragedy and to technology. It is not enough to ask what happens to epic when it is exposed to different technologies, however appropriate that might seem for epic in its most familiar modern locus, the screen. Instead, 'What does epic do to stage technologies?' is the pertinent question to ask of Titian 2012, as Shawcross's robot at the heart of Machina makes clear. The robot is a complex piece of industrial machinery, which was originally part of a production line in Poland. During the course of the ballet, it became uncannily human and increasingly suprahuman as it sinuously danced and then destroyed, Diana-like, the hunter who ventured too near. Shawcross's robot is no god out of a machine - the god is the machine; and with 3000 watts running through its cables, it was a truly dangerous machine.

\section{Epic on the Early Modern Stage}

Recreations of epic poetry realized in dramatic performance have provided the staple of the performance repertoire since antiquity. The interconnections and interdependence between ancient epic and ancient drama have long been acknowledged, both in terms of content (epic heroes and themes provide the staples for both tragedy

\footnotetext{
${ }^{6}$ Cited in Moore Ede, Titian (n.1 above), p. 106.
} 
and comedy) and form (tragedy's messenger speech, in particular, is a clear 'surviving' epic feature). Aristotle, however, also insists on their differences - in terms of scale, epic can sweep across time and place and can handle episodes concurrently (Poetics, chapters 23-4); and epic, unlike tragedy, is allowed to include the marvellous because, we infer, it is imagined and so not (implausibly) seen on stage (chapter 24). These interconnections and differences have been much debated in the modern world from the advent of neo-classical theory onwards, when the epic elements of drama were increasingly banished from serious spoken drama. ${ }^{7}$

The confinement of the gods in Greek tragedy to the prologue/epilogue, and spatially to the theologeion (the stage roof) and to the méchan $\bar{e}$ (the mechanical crane that winched gods from the stage building into the sky) is testament to the perceived problems in antiquity of including the gods on stage. Dionysus in the Bacchae is the exception who proves the rule here. When Aristotle gives Medea's exit on her chariot ex machina at the end of her eponymous tragedy as an example of how not to use the $\bar{e} \bar{e} c h a n \bar{e},{ }^{8}$ it is, we infer, because the machine must not grow organically from the events of the rest of the play. According to Aristotle, the méchane is reserved solely for the miraculous entries of the divine rather than serving as a device for any (albeit here divinely descended) mortal to effect their own escape. The fourthcentury comic poet, Antiphanes, offers a mechanistic view of the mēchane, which is funny precisely because it tells only half of the story. For Antiphanes, the tragic poets: "when they have nothing more to say/ and have totally run out of steam in their plays,/ they lift the crane like their finger/ and for the audience this is satisfactory'. 'Indeed, if Greek tragedy's focus is predominantly on the real - on how the divine impacts on the real (polis/oikos) - epic, by contrast, shows how the real and the hyper-real are, in reality, so close that they are almost one and the same. As Heaney says, epic creates a mythosphere within which the imagination has free play; ${ }^{10}$ and when epic comes to the theatre in the modern period, its differences from tragedy prove both a gift and a potential stumbling block.

Early modern English drama predominantly took its cues from the tragedies of Seneca; but with the publication of Latin and vernacular translations of Euripides, in particular, Greek tragedy also provided a regular model. ${ }^{11}$ Additionally, by the mid-sixteenth century epic provided the popular theatre with raw material as well. The highly influential translation of Ovid by Lodovico Dolce (1553) appeared three years before Titian began his paintings - the Italian poet is generally regarded as

\footnotetext{
7 F. Macintosh, 'Epic Transposed: the Real and the Hyper-Real During the Revolutionary Period in France', in Epic Performances from the Middle Ages into the Twenty-First Century, ed. F. Macintosh, J. McConnell, S. Harrison and C. Kenward, Oxford, 2018, pp. 476-92.

8 Aristotle, Poetics, 14. 1457a-1457b.

9 Poiēsis, fr.189, in Poetae Comici Graeci, Berlin 1981-, ed. R. Kassel and C. Austin, pp. 12-15. On stage machinery generally, see the discussion by P. Möllendorf, 'Technologies of Performance: Machines, Props and Dramaturgy', in A Cultural History of Theatre in Antiquity, I, ed. M. Revermann, London, 2017, pp. 165-182.

${ }^{10}$ Heaney in conversation with Alan Yentob in 'Dancing With Titian' (n. 1 above).

11 See the essays Homer and Greek tragedy in Early Modern English Theatres, ed. T. Dimitriou and T. Pollard, Classical Receptions Journal, special issue, 9, 2017.
} 
his main source and his interlocutor - and Arthur Golding's translation that was to influence Shakespeare and his contemporaries was published shortly after (1567). And when Chapman's translations of both the Iliad (from 1598) and Odyssey (1616) appeared a few years later, ancient epic informed not only the content of new drama (say, A Midsummer Night's Dream, Troilus and Cressida), but its form as well. Epic in this period was broadly conceived as encompassing both the 'martial'/'heroic' Iliadic model and the Odyssean/romance model; and it was the Odyssean model, with its dependence on suspense and recognition, that was translated on to the stage as tragicomedy and especially the late plays/'Romances' of Shakespeare. ${ }^{12}$

In addition to these textual innovations attendant on those early encounters with ancient epic in the vernacular, there are also notable ways in which the ancient epic poems led to innovations in scenic design. Italian perspectival scenery and painted flats in grooves on stage, which opened in sequence to reveal varied scenes, ${ }^{13}$ made it possible to stage epic-scale plots across time and place inside the medieval dining halls of Europe. When the architect/designer, Inigo Jones collaborated with the poet/ playwright, Ben Jonson in the Stuart Masques at court between 1605-1631, cloud machines and flying devices afforded spatial expansion on the vertical as well as the horizontal level.

The translations of the Homeric epics had ushered into the modern world immanent, though frequently absent, pagan gods, who occasionally arrived to resolve human crises. If the medieval period saw the Greco-Roman pantheon through a contemporary lens, with gods dressed as medieval monks, by the late fifteenth century the ancient gods resembled the Greco-Roman statues that were beginning to be excavated in Italy. ${ }^{14}$ Now in the English Masques at Court, where the pagan deities were invoked at critical junctures, complex machinery (as in the ancient theatre) was required to facilitate their entries and exits. The Masques, which included music from leading composers and the most celebrated dancing masters of the age, were the first serious attempts in the modern world to recreate the ancient synthesis of the arts. ${ }^{15}$ These scenic devices were not simply mechanistic but emblematic of divine order mirrored on stage through the human mind's mastery over the natural world. ${ }^{16}$ The hyper-real - the world of wonder and revelation that alone, according to Aristotle, justified the use of the deus ex machina ${ }^{17}$ - is the true preserve of the masque.

\footnotetext{
12 S. Dewar-Watson, 'Aristotle and Tragicomedy', in Early Modern Tragicomedy, ed. S. Mukherji and R. Lyne, Cambridge, 2007, pp. 15-27. See also W. Williams, 'Monsters and the Question of Inheritance in Early Modern French Theatre', in Epic Performances from the Middle Ages, ed. Macintosh et al. (n. 7 above), pp. 103-18.

13 L. Campbell, Scenes and Machines on the English Stage During the Renaissance: A Classical Revival, New York, 1960; S. Rosenfeld, A Short History of Scene Design in Great Britain, Oxford, 1973.

14 B. Graziosi, The Gods of Olympus: A History, London, 2014, pp. 187-8.

15 F. Yates, The French Academies of the Sixteenth Century, London, 1947; S. Orgel, The Illusion of Power: Political Theater in the English Renaissance, Berkeley and London, 1975.

16 D. Lindley, 'The Stuart Masque and Its Makers' in The Cambridge History of British History, I: Origins to 1660, ed. J. Mulling and P. Thomson, Cambridge, 2004, pp. 383-407.

17 Aristotle, Poetics, 14. 1457a-1457b.
} 
In the Stuart court, the iconoclasm of the Reformation was now being recalled in a process of 're-membering' in the secular spectacles on stage. ${ }^{18}$

But Jones and Jonson's longstanding relationship eventually ended in a bitter dispute over whether the verbal or the visual should dominate in the masque. Jonson at the height of their dispute mordantly satirized Jones's position through the figure of Poet in his Expostulation with Inigo Jones: 'O shows! Show! Mighty shows!/ The eloquence of Masques! What need of prose/Or verse, or sense, t'express immortal you! ${ }^{19}$ Jonson here is railing against what he sees as the increasing monomania of Jones, the designer; and there is a very real sense in which the masques evidenced both the court's conspicuous consumption and the glorification of the monarch. However, Jones always claimed that he was merely putting the visual on a par with the word and the music, as had been the case in antiquity. ${ }^{20}$

That there is a serious case to be made for epic rather than the ego as the driving force behind the stage innovations of Jones and others in the early modern period is well illustrated a few years later at the Hôtel du Petit-Bourbon in Paris (1650). Here Corneille's Andromède included, thanks to the designs by the celebrated Italian set designer, Giacomo Torelli, a flying horse (apparently a real one appeared in a revival at the Comédie Française in 1682) in order to transport Perseus through the air to Andromeda's rescue.

\section{Excluding Epic from Serious Drama}

The dispute between Jonson and Jones - between word and spectacle - is played out in various ways during the next few centuries. Neoclassical theorists from the 1650s began devising 'rules' for epic, as they had done already for tragedy, in order to fill in the blanks left by Aristotle's sketchy account in the Poetics. As Robertson has argued, it was precisely these restrictive rules that strangled epic's imaginative potential and paradoxically secured its insecurities in the long run. ${ }^{21}$ Furthermore, the proscriptions against the essential ingredients of epic in tragedy on the grounds that they breached verisimilitude - its leaps across time and place into hyper-real worlds - guaranteed their migration to other genres.

During the course of the eighteenth century, 'epic' elements on stage are finally excluded from serious spoken drama and are coralled, in turn, within opera and dance, or confined to the unofficial stages of the fairs, where they had been flourishing since the seventeenth century. Epic, it seems, could either be 'low' (in other words, burlesqued as it had been since antiquity and so confined to the fairs or to the Comédie-Italienne) or transported to the realms of hyper-reality on the operatic/

\footnotetext{
18 K. Reilly, Automata and Mimesis on Stage: The History, Basingstoke, 2011.

19 In The Cambridge Edition of the Works of Ben Jonson. VI, ed. D. Bevington, M. Butler and I. Donaldson, Cambridge, 2012, 375-9.

${ }^{20}$ F. Macintosh, 'Modern Stage Design and Greek Antiquities: Inigo Jones and His Greek Models', in Hellenomania, ed. K. Harloe, N. Momigliano and A. Farnoux, London and Athens, 2018, pp. 23-39.

21 R. Robertson, Mock Epic Poetry from Pope to Heine, Oxford, 2009.
} 
ballet stages. Whilst some neo-classical theorists had argued that the gods could make the marvellous vraisemblable, by the mid-eighteenth century, in an age of growing religious scepticism, this view was no longer tenable. When Voltaire set about the revisions for his tragedy, Sémiramis (1748) - following the controversy caused by its ghost scene in Act 2, in which King Ninus rises from his tomb very much like Darius in Aeschylus's Persians - the playwright explained:

I am giving more tragic and less epic elements, I am substituting, as much as possible, the real for the marvellous. However, I am keeping my ghost. ${ }^{22}$

Voltaire's desire to move further towards 'the real' and away from the marvellous, towards 'tragedy' and away from 'epic', captures the mood of the moment. Now Lillo's proto-bourgeois tragedy, The London Merchant (1731) is the preferred model for the new tragedy.

By 1781, the literary critic and philosopher, James Harris can praise both Sophocles's Oedipus Tyrannus and Lillo's Fatal Curiosity (1737) on the grounds that they avoid 'using machines, Deities, Prodigies, Spectres, or anything else, incomprehensible, or incredible'. ${ }^{23}$ As the French philosopher, Charles Batteux argued in Les beaux arts réduits à un même principe (1746), the divine element of epic on stage is 'the marvellous'; and it is this divine element, above all, that makes epic an increasingly inappropriate dramatic model during the course of a century that narrowly restricts the 'real' in the theatre to the domestic house (oikos) and the village/town/ city (polis). ${ }^{24}$

It is possible to trace this interplay between technological innovation and epic on stage throughout the eighteenth century and into the nineteenth, but not in serious spoken drama: epic not surprisingly finds its natural locus in either grand opera (say, Berlioz's Les Troyens, 1863) or in burlesque (say, Offenbach's La Belle Hélène, 1864). By the early twentieth century, Brecht casts his 'epic' theatre against tragedy, but especially against the excessive scale and clutter of nineteenth-century spectacular theatre in order to recuperate the 'narrative'/telling of epic (both of the internal and external kind that Ovid so brilliantly does in his account of the death of Actaeon). ${ }^{25}$ Though Brecht, like his fellow Expressionists, fully exploited the innovations in stage technology, he did not do so to mimic any masterly providential hand. For Brecht, jettisoning the 'showy' displays of technological bravura of bourgeois, illusionist theatre was essential; and for that reason, he deliberately exposed the

\footnotetext{
${ }^{22}$ Letter to Formont, cited (but wrongly dated to 1732) in T. W. Russell, Voltaire, Dryden and Heroic Tragedy, New York, 1946, p. 89.

23 Cited in C. Green, The Neo-Classical Theory of Tragedy in England During the Eighteenth Century, Cambridge MA, 1934 p. 157.

24 C. Batteux, Les beaux arts réduits à un même principe, Paris, 1746.

25 See I. Gildenhard and A. Zissos, 'Somatic Economies: Tragic Bodies and Poetic Design in Ovid's Metamorphoses', in Ovidian Transformations: Essays on Ovid's Metamorphoses and Its Reception, ed. P. Hardie, A. Barchiesi and S. Hinds, Cambridge, 1999, pp. 162-81 (174), for an interesting discussion of the 'false mask of the deer' in terms of exterior and interior narration and the shift from semiotic play to somatic trauma.
} 
operations and the functionality of theatrical machines, as his use of film projections alongside crude placards well illustrates.

If Brechtian de-cluttering held sway in avant-garde theatrical circles for most of the twentieth century, in recent years, the full epic sweep and epic spectacle are resurfacing in the theatre. It is as if theatre is reclaiming what the potentially vast spatial leaps characteristic of film have appropriated and is now reinjecting the kind of excitement into theatrical performances that has been developed elsewhere in, say, live musical festivals. A very good example of this 'epic' turn is the five-hour production of Les Troyens - the first time since its 1863 premiere that the opera had not been cut - that was performed the same month as Titian 2012 at the Royal Opera House. Directed by David McVicar, the designs were by Es Devlin, whose work that summer also included the Closing Ceremony for the Olympics and who had the previous year designed a twenty-foot metal man for a 'Take That' tour, which was widely reported to lie behind the design for her Trojan Horse at Covent Garden. Devlin's Trojan Horse was a vast metal war machine made up of shields and missiles that was sited within a colossal set. Is this crude, showy spectacle, as Ben Jonson said of Inigo Jones's increasingly elaborate designs for the Stuart Masques? Or is it something inherent in performances of epic on stage? As Batteux explained, the 'marvellous' that is the hallmark of epic is not incompatible with the real; it is simply the divine element of epic and becomes another heightened version of the 'real' when it is translated to the stage.

\section{Machina}

The idea that machines pose a threat to humanity is relatively recent. In Iliad Book XVIII, Hephaestus is making a series of automata, twenty tripods on golden wheels so that they can go of their own accord to the assembly of the gods and return independently to his workshop - 'a wonder to look at' (Iliad, XVIII.373-7). Similarly, in Odyssey Book VII, Odysseus marvels at the Phaeacian king's palace, whose entrance is guarded by immortal gold and silver dogs crafted by Hephaestus (Odyssey, VII.91-4). In early modern England, as we have seen, the stage machinery developed by the architect Inigo Jones and others was not simply something to marvel at; it mirrored the workings of the cosmos and celebrated human control over a natural world that was increasingly viewed as the perfect machine controlled by god. For Descartes, bete machine had designated the lack of reason of animals; whereas with an increasingly mechanized labour force from the late eighteenth century onwards, it is both the human face of the machine (as with Mary Shelley's Frankenstein) and the machine-like working conditions of the exploited labouring classes that lead to the total rejection of Cartesian mechanistic philosophy.

It is precisely the liminality of the automata - that they are both like and unlike humans - that makes them alluring and threatening. This is especially true in the posthuman world of today, where the boundaries between human and machine are increasingly blurred and 'artificial intelligences are not merely tools. They are 
potentially independent agencies' ${ }^{26}$ According to prominent theorist of the posthuman, Rosi Braidotti, this is liberating rather than terrifying: '... the posthuman subject [is] ... a composite assemblage of human, non-organic, machinic and other elements.... This extended self is moreover marked by the structural presence of practices and apparati of mediation that inscribe technology as "second nature".,27 Braidotti, whose previous work in this area had no doubt significantly included a nod towards Ovid, goes on to argue that the posthuman is not about dehumanization of the subject; rather, it entails 'a new way of combining ethical values with the well-being of an enlarged sense of community, which includes one's territorial or environmental inter-connections'. ${ }^{28}$

Shawcross engages very much with the questions raised by the posthuman turn in philosophy. He first encountered the robot somewhere in Poland carving a piece of wood. The carving was done with such precision that Shawcross's initial reaction was that the robot's skill presented what was almost a personal challenge to him as an artist, whose own kinetic sculptures are often informed by mathematical, philosophical and scientific theories. ${ }^{29}$ Shawcross interestingly casts himself in the role of hunter/Actaeon in his account of one such encounter with a robot: 'You stop in your tracks and survey this thing to work out whether it is a threat or benign, whether it's a friend or foe ... it's as if you were coming across a wild boar or a bear in a forest'. 30

It wasn't simply the robot, however, who presented the abstract sculptor with a challenge: Shawcross, the sculptor, had to grapple with Titian's pre-eminence as a painter and to seek equivalents to Titian's innovations in the way he applied paint to his canvas:

...there's a danger of forgetting that [the works in the National Gallery] ... were once contemporary and once deeply shocking ... or controversial. Artists have always had to embrace new technologies to create the works of the day, whether that's mixing eggshells or using lapis lazuli from Afghanistan, like Titian did. Venice was a hotbed of new ideas, new processes. And so this robot, while it might look weird in the gallery, is no different. ${ }^{31}$

If the sculptor's first encounter with the robot is presented in terms analogous to hunter and quarry, the terms soon become increasingly anthropomorphic: 'it moves

\footnotetext{
${ }^{26}$ N. Bostrum, Director of the Future of Humanity Institute, University of Oxford, cited by A. Bandarage, 'A Post-Nature, Post-Human World?', Huffington Post, Blog post, 17/8/2013.

27 R. Braidotti, 'Posthuman Critical Theory', in Critical Posthumanism and Planetary Futures, ed. D. Banerji and M Paranjape, New York and Delhi, 2016, p. 19. See the earlier 'nod' to Ovid in R. Braidotti, Metamorphoses: Towards a Materialist Theory of Becoming, Cambridge, 2002.

28 Braidotti, 'Posthuman Critical Theory' (n. 27 above), pp. 26-7.

29 Moore Ede, Titian (n. 1 above), p. 23. I am also indebted to Shawcross himself for taking time to show me round his studio in East London and for allowing me to interview him for this article on 13 March 2017. The robot came from Poland, where it had had a working life, but was purchased via a dealer in Spain.

${ }^{30}$ Moore Ede, Titian (n.1 above), p. 78.

31 Ibid., p. 79.
} 
in such a beguiling, such a human way'. ${ }^{32}$ Shawcross and his team went on a twoweek course in Cirencester learning to 'communicate' with the robot. ${ }^{33}$ The robot's light-tipped proboscis is soon seen as a 'human arm ... [with] an elbow, and a wrist... But it also has a finger than can rotate constantly - so it's superior to the human arm in some ways'. ${ }^{34}$

According to Shawcross, Diana is like technology, which is seductive and yet induces fear; she is cold and beautiful (like the robot), but has no heart; and yet, after seeing the robot in the gallery, men (according to the sculptor) reported that they had fallen in love with her. ${ }^{35}$ Here we can see how the Ovidian story has driven the technology: 'the story itself was the most important thing, and its essence was at the core of everything I was trying to achieve'. ${ }^{36}$ What Machina captures so brilliantly is the Ovidian dual perspectives, which culminate in the hunter becoming the quarry and Actaeon's witnessing of his own bloody end as both internal and external spectator, tragically retaining an awareness of who he is whilst having lost the outward signs of his identity: 'His companions] complain that he is absent, and that, slow, he does not perceive the spectacle of this fortuitous prey. He would indeed wish to be absent, but he is present, and he would rather watch than feel the cruel deeds of his dogs' (Metamorphoses, III.245-8). ${ }^{37}$

So important indeed was Ovid's story for Shawcross that he worked with a storyboard - 'a timeline of mood' - with a very clear narrative drive: column one, for example, is headed 'The Forest', and includes a description of the robot Diana's faint light behind the screen alongside details drawn from Ovid of a 'mysterious', 'beautiful', 'mesmeric' Diana and a 'bold', 'young', 'fearless', 'dynamic' Actaeon. Aloof at first, the twenty-five-foot high metal monster broods on the horizon behind the screen, shrouded in fog (analogous to the magical dimension of Ovid's own landscapes), and only the light on the end of its wand discernible in the distance.

The second column in Shawcross's timeline, entitled 'Bath Scene', traces the partial reveal of the giant robot still obscured behind screens, her seductive, sensuous power and Actaeon's ardour. If hunting in Ovid is a kind of surrogate violent sex, ${ }^{38}$ the two partners here (Ed Watson and Tamara Rojo, Carlos Acosta and Leanne Benjamin) prey upon each other with desirous intent during their pas de deux. The third column, 'The Realisation', is marked by Diana/robot rising up to full height, the full reveal with the removal of the screens and the concomitant fear and regret of Actaeon. The last three columns mark the final sequences: 'The Spell' (including the robot's full orbit of the stage); 'The Metamorphosis' (when the robot comes to a stop and looms over the stage); and 'The End/The Devouring' (when the robot

\footnotetext{
32 Ibid., p. 78.

33 Ibid., p. 91.

34 Ibid., p. 92.

35 Interview with Shawcross, 13 March 2017.

36 Moore Ede, Titian (n. 1 above), p. 78.

37 For the translation and illuminating commentary on Actaeon's death, see A. Feldherr, Playing Gods: Ovid's Metamorphosis and the Politics of Fiction, Princeton, 2010, pp. 39-40 and 177.

38 S. Hinds, 'Landscape and the Aesthetics of Place in the Metamorphoses and its Tradition', in The Cambridge Companion to Ovid, ed. P. Hardie, Cambridge, 2002, pp. 122-49 (135-6).
} 
lowers and returns to a slow functional movement, as if, like in The Death of Actaeon with the skull in the background, this is the calm before the next victim, waiting in the wings, appears). ${ }^{39}$

What clearly attracted Shawcross to the timeline was how it neatly conveys the mirroring implicit in Ovid's tale - the hunter becomes the hunted, the victim of voyeurism becomes agent of revenge - and how in turn, the ballet Machina reproduced the mirroring that is apparent between Titian's two paintings, Diana and Actaeon and The Death of Actaeon. As Shawcross observes:

... if you lay the two [Titian] works over one another, you see that they are actually the same compositionally or very similar, with the figures in near identical poses and a diagonal shooting across the canvas between them. ${ }^{40}$

With its five-part structure and its central pivotal scene - 'The Realisation' - the mirror structure of Machina is very classical and yet also 'epically' fluid. But Shawcross's notion of narrative process did not please everyone; especially not those reared, like Wayne McGregor, on modernist ballet aesthetics, for whom, dance itself, and not the story, is the goal of dance. ${ }^{41}$ Shawcross's vision, however, prevailed because the story he found in Ovid did drive the technology in important ways.

Diana/robot, in Shawcross's view, had to dance; and she/it, in fact, performs the sinuously undulating movement patterns of Ed Watson (one of the Actaeons), whose movement vocabulary was captured by motion capture was then mapped onto those of the robot/Diana at Imperial College by Shawcross and his team. This provided a chilling example of how life animates art and art in turn shapes life. As Ed Watson commented, the robot thus becomes a real presence, not just a built object. ${ }^{42}$ When Carlos Acosta (the second Actaeon) ventures too close to the robot in the second sequence of the ballet, she/it goes wild, and the divine, powered by the human, chillingly destroys the human.

Brandstrup, as we have heard, has commented illuminatingly on the challenges and the opportunities afforded by this veritable Gesamtkunstwerk. But there were in reality three choreographers to Machina, the third being Shawcross. As we find at the heart of Ovid's tale, power relations in Machina were literally shifting all the time - but here, the shifts are not just those between Actaeon and Diana, the robot and the sculptor, the robot and the dancers. Also in the mix here, as in all dance, those power relations are between the dancers and choreographers; and especially in Machina the balance between choreographers and the sculptor. But one should not forget Nico Muhly, the composer, whose chord at the outset had enabled Shawcross to begin his work, and which in turn created the computer simulation of the

\footnotetext{
39 There is no original of this timeline, which, according to Shawcross in conversation, 13 March 2017, somehow got lost at the Opera House. It is, however, reproduced in Moore Ede, Titian (n. 1 above), p. 93. Shawcross also drew attention to the links between his final sequence and The Death of Actaeon.

40 Moore Ede, Titian (n. 1 above), p. 78.

41 Interview with Shawcross, 13 March 2017.

42 Watson in 'Dancing with Titian' (n. 1 above). See also M. Payne, The Animal Part: Human and Other Animals in the Poetic Imagination, Chicago and London, 2011, pp.128-31. Payne makes a case-study of Ovid's Acteaon from the perspective of posthumanism.
} 
robot's movements that were replicated on Tamara Rojo's costume. ${ }^{43}$ Nowhere in recent memory has the terrifying power of the Greco-Roman deities been so effectively conveyed on the stage (witness the recent embarrassment of Simon Armitage's Last Days of Troy at the Manchester Royal Exchange and then at the Globe in 2015, with Olympian gods straight out of Offenbach's La Belle Hélène). This success was the result, in large measure, of this complex, sometimes controversial (posthuman, perhaps?) collapsing of boundaries between self and others, the human and the machine, the natural and the supernatural, the real and the hyper-real.

Epic with its links to the marvellous readily affords a kind of hyperspace that unleashes potential - creative and often technical; and it is this hyperspace that makes it a constant allure for practitioners. Tim Supple, who directed Tales from Ovid for the RSC at the Barbican a few years ago, insists that 'epic' theatre is not 'spectacular' theatre. ${ }^{44}$ It is not about 'conducting' from afar - so he would presumably rule out McVicar's 2015 production of Berlioz's Les Troyens. But since Supple insists on the collective experience being at the heart of 'epic', I suspect that he would feel differently about Machina: here with the dancers downstage, we have a brilliant illustration of how we are both within and beyond this world at one and the same time. We are both internal spectators and also spectators proper as we vicariously parallel Actaeon's own dual agonizing perspective in Ovid's account of his death.

There is an interesting coda to Machina: Shawcross's small rehearsal robot enjoyed an afterlife when it came centre stage in June 2017 at the Barbican, in a collaborative project entitled Into the Unknown: A Journey through Science Fiction, curated by Patrick Gyger. Here the robot performed a light show strikingly reminiscent of Loie Fuller's early twentieth-century dance dramas, in which her illuminated silk costume, extended by vast wing-like sticks, allowed her to become literally engulfed in the fabric as she danced. Fuller's dances not only led to Mallarmé's coinage écriture corporelle, they also inspired Yeats's teasing riddle in 'Among School Children': 'O body swayed to music, $\mathrm{O}$ brightening glance,/ How can we know the dancer from the dance?' ${ }^{45}$ If Fuller's artworks emblematized the collapsing of boundaries between subject/artist and object/artwork and thereby created what was understood as the modernist ideal artwork, so now, in the posthuman world, is Shawcross's robot reminding us that dance can dispense with the agency of the human dancer altogether?

Open Access This article is distributed under the terms of the Creative Commons Attribution 4.0 International License (http://creativecommons.org/licenses/by/4.0/), which permits use, duplication, adaptation, distribution and reproduction in any medium or format, as long as you give appropriate credit to the original author(s) and the source, provide a link to the Creative Commons license and indicate if changes were made.

Publisher's Note Springer Nature remains neutral with regard to jurisdictional claims in published maps and institutional affiliations.

\footnotetext{
43 Moore Ede, Titian (n. 1 above), p. 100.

44 T. Supple, 'Theatre on an Epic Scale', in Epic Performances from the Middle Ages, ed. Macintosh et al. (n. 7 above), pp. 46-62.

45 W. B. Yeats, 'Among School Children', in The Major Works, Oxford, 2001, p. 113.
} 